\title{
Special and Differential Treatment Commitments Provided to Developing Countries
}

\subsection{Introduction}

This paper examines special and differential treatment commitments and provisions in the GATS, the DDA offers, and key North-South and South-South regional trade agreements, as summarised in Table 2.1.

Table 2.1. SDT aspects of the GATS, DDA and selected RTAs

\begin{tabular}{|c|c|c|c|}
\hline & GATS & DDA & RTAs \\
\hline Architecture & Great flexibility & Same as GATS & Great flexibility \\
\hline $\begin{array}{l}\text { Recognition of non- } \\
\text { reciprocity for } \\
\text { developing countries }\end{array}$ & Yes & Yes & Recognised in a few RTAs \\
\hline Negotiated outcomes & $\begin{array}{l}\text { Many fewer } \\
\text { commitments by } \\
\text { developing countries }\end{array}$ & $\mathrm{n} / \mathrm{a}$ & $\begin{array}{l}\text { Many fewer commitments } \\
\text { by developing countries }\end{array}$ \\
\hline $\begin{array}{l}\text { Technical assistance } \\
\text { (TA) }\end{array}$ & $\begin{array}{l}\text { To be provided by WTO } \\
\text { rather than members; } \\
\text { no commitments as } \\
\text { to time or amount; } \\
\text { in practice small } \\
\text { amounts provided }\end{array}$ & $\begin{array}{l}\text { Called for by } \\
\text { negotiating } \\
\text { documents }\end{array}$ & $\begin{array}{l}\text { Very few RTAs call for } \\
\text { TA and these contain no } \\
\text { commitments as to time } \\
\text { or amount }\end{array}$ \\
\hline $\begin{array}{l}\text { Longer time for } \\
\text { implementation }\end{array}$ & $\begin{array}{l}\text { None for general } \\
\text { obligations; market- } \\
\text { opening commitments } \\
\text { can be delayed by } \\
\text { making pre-commitments }\end{array}$ & $\mathrm{n} / \mathrm{a}$ & $\begin{array}{l}\text { A few RTAs allow } \\
\text { additional time for } \\
\text { implementation }\end{array}$ \\
\hline $\begin{array}{l}\text { 'Best endeavours' } \\
\text { clauses }\end{array}$ & Yes & Yes & Contained in a few RTAs \\
\hline
\end{tabular}

As mentioned in the introduction, asymmetry of outcome is viewed by some as a form of SDT that is built into the structure of the agreements, and it is potentially the most significant. We therefore begin our analysis with a discussion of the architecture of the GATS and services RTAs that allows for asymmetrical results, followed by a description of provisions that acknowledge that developing countries (and LDCs) are not expected to make as many commitments as developed countries. We next examine the outcomes of the negotiations, in terms of the number of commitments (in the case of positive list agreements) or the number of non-conforming measures (in the case of 
negative list agreements) in order to determine the extent to which the developing country parties have in fact committed to a lesser degree of market opening than the developed country parties. We then describe other provisions in the agreements that provide SDT: technical assistance, time-limited derogations from obligations and 'best endeavour' clauses. Finally, this section provides a brief discussion of the pros and cons of STD.

\subsection{Architecture of services trade agreements}

\subsubsection{The GATS}

The GATS gives great flexibility to WTO members as to the extent to which they open their service markets to foreign competition. The ways in which they can exercise that flexibility include the following:

- The GATS uses the positive list or 'bottom-up' approach. Under this approach each member chooses for itself which service sectors and sub-sectors and which of the four modes of supply ${ }^{9}$ on which to make market-opening commitments, and there is no minimum requirement as to the number of commitments that must be made. ${ }^{10}$ This contrasts with the 'negative list' or 'top-down' approach used in some RTAs, under which all sectors and sub-sectors are opened, except with respect to scheduled non-conforming measures.

- Even where a member decides to open a particular sector, it can place market access limitations on foreign service suppliers with respect to the number of suppliers, the volume of trade, the number of natural persons who may enter, the legal form of the service supplier and the maximum percentage of foreign capital (GATS Article XVI).

- In contrast to the GATT and many of the Uruguay Round agreements on trade in goods, which require national treatment in all cases (except government procurement), under the GATS members can continue to discriminate against foreign service suppliers even in sectors and modes in which they have made market-opening commitments, provided that they list a national treatment exception in their schedules (GATS Article XVII).

- Members were not required to open scheduled sectors or sub-sectors immediately, but instead could undertake to open them at some future time (GATS Article XX.1 (d)).

- During the Uruguay Round negotiations members were permitted to take exceptions to the MFN principle, although 'in principle' these were not to exceed ten years (GATS Article II.2).

- Members were not required to make commitments that corresponded to their actual degree of market opening. Thus, in many cases service markets are considerably more open than reflected in the GATS commitments. 


\subsubsection{The Doha Development Round}

The services negotiations in the DDA follow the same positive list approach as in the Uruguay Round.

\subsubsection{Regional trade agreements}

Many RTAs use the positive list approach described above. This is generally preferred by developing countries, since there is little danger of inadvertently including a sector or sub-sector which the country did not intend to schedule. Other RTAs, however, use the so-called negative list approach, under which all service sectors are presumed to be opened except to non-conforming measures that are scheduled. This is a more transparent procedure, since all barriers to service trade are scheduled, whereas in the case of the GATS-type, positive list approach, barriers are only scheduled with respect to sectors and sub-sectors in which commitments have been made. The USA and Canada, in particular, prefer the negative list design. It requires rigorous preparation, as every barrier to trade in services, not just those in the sectors where commitments are to be made, must be inventoried before negotiations begin. In the view of some, this approach is less flexible than the positive list approach because the exceptions, rather than the market-opening commitments, have to be negotiated.

\subsection{Provisions acknowledging that reciprocity is not expected from developing countries}

\subsubsection{The GATS ${ }^{11}$}

GATS Article XIX specifically acknowledges that developing country members are not expected to open their service markets to the same extent as developed country members:

There shall be appropriate flexibility for individual developing country Members for opening fewer sectors, liberalising fewer types of transactions, progressively extending market access in line with their development situation and, when making access to their markets available to foreign service suppliers, attaching to such access conditions aimed at achieving the objectives referred to in Article IV.

Even more flexibility was given to LDCs. Paragraph 3 of Article IV provides that:

Special priority shall be given to the least-developed country Members in the implementation of paragraphs 1 and 2. Particular account shall be taken of the serious difficulty of the least-developed countries in accepting negotiated specific commitments in view of their special economic situation and their development, trade and financial needs

As discussed in Section 2.4 below, the level of commitments made by developed coun- 
tries in the Uruguay Round GATS negotiations was significantly higher than that for developing countries, reflecting the built-in asymmetry.

The GATS also gives greater flexibility to developing countries with respect to RTAs. GATS Article V.1 authorises WTO members to enter into agreements liberalising trade in services, provided that the agreements have 'substantial sectoral coverage' in terms of the number of sectors, the volume of trade affected and the modes of supply, and that they provide for the elimination of 'substantially all discrimination' in the sectors covered by the agreement. 'Substantial sectoral coverage' has not been interpreted by WTO panels or by the appellate body. The comparable term 'substantially all of the trade' in Article XXIV of the GATT (which authorises regional trade RTAs covering trade in goods) is generally considered by experts to mean somewhere in the order of 80 to 90 per cent (Sauvé and Ward, 2009; Scollay and Grynberg, 2005), and 'substantial sectoral coverage' in GATS Article V can reasonably be interpreted as falling within the same range.

However, Paragraph 3 (a) of Article V calls for flexibility with respect to the Article V.1 conditions ('especially the elimination of substantially all discrimination') where developing countries are 'parties to' a services trade agreement, 'in accordance with the level of development of the countries concerned'. ${ }^{12}$ Other than the reference to 'the level of development', the extent of this flexibility is not spelled out in the agreement, and it has not been discussed by WTO panels or by the appellate body. ${ }^{13}$

\subsubsection{The Doha Development Round}

As part of the Doha Development Round, several documents have been agreed by WTO members that call for special treatment for developing countries. ${ }^{14} \mathrm{With}$ respect to asymmetry of outcome, the negotiating modalities agreed for the Doha Development Round contain the same emphasis on flexibility as does the GATS. The Guidelines and Procedures for the Negotiation on Trade in Services (S/L/93, adopted on 29 March 2001) and the 'July 2004 Package' (WT/L/579, 2 August 2004) recognise the need to provide flexibility for developing countries in negotiations in similar or identical terms as Article XIX.2 of the GATS. In addition, the Hong Kong Ministerial Declaration (WT/MIN(05)/DEC, adopted on 22 December 2005), calls for special attention to be paid to sectors and modes of supply of export interest to developing countries. Finally, the 'July 2008 Package' stated that:

Commitments shall be commensurate with the levels of development, regulatory capacity and national policy objectives of individual developing countries. ${ }^{15}$

With respect to LDCs, the Modalities for the Special Treatment for Least Developed Country Members in the Negotiations on Trade in Services (TN/S/13, 5 September 2003) states that members should not seek the removal of conditions that LDCs impose on market access; that LDCs are to be given flexibility in terms of opening fewer sectors and liberalising fewer transactions; and that they are not expected to provide full national treatment. The document also calls upon members to take measures aimed at 
increasing the participation of LDCs in trade in services. The Hong Kong Ministerial states clearly that LDCs 'are not expected to undertake new commitments' (WT/MIN(05)/DEC, 18 December 2005).

The DDA offers are in the form of proposed schedules, and therefore do not contain any specific proposals for SDT provisions, such as technical assistance. However, two developed country offers pay at least lip service to SDT. New Zealand's revised offer 'takes particular account of requests for liberalisation of market access in sectors and modes of supply of interest to developing countries, and includes new and improved commitments in Mode 4' (TN/S/O/NZL/Rev.1, 17 June 2005). The EC revised offer states that it was made in consideration of the requests that had been received, particularly those from developing countries (TN/S/O/EEC/Rev.1, 29 June 2005).

\subsubsection{Regional trade agreements}

Few of the agreements we have examined contain provisions acknowledging that reciprocity is not expected from the poorer members. The Association of Southeast Asian Nations (ASEAN)-China and ASEAN-Korea free trade agreements call for flexibility for the newer ASEAN members (Cambodia, Laos, Myanmar and Vietnam) in terms of opening fewer sectors and liberalising fewer types of transactions. Four agreements, USA-Chile, USA-Peru, USA-Morocco and Canada-Peru, simply declare that transparency mechanisms for small agencies in the developing country party may have to take account of budget constraints. The Chile-Canada Free Trade Agreement (FTA) reserves for Chile the right to adopt currency measures to maintain currency stability.

\subsection{Negotiated outcomes}

\subsubsection{The GATS}

A number of studies have shown that the developing countries did indeed make significantly fewer commitments in the Uruguay Round than did the developed countries. ${ }^{16}$ Simply comparing the number of commitments is a fairly crude way of measuring market opening. It reflects neither the volume of trade in a particular sector or subsector, nor the extent to which the commitments are subject to scheduled limitations. However, given the data inadequacies, ${ }^{17}$ it is probably the only practical approach to this exercise.

\section{Commitments by sector}

The available data can be analysed in various different ways, each of which shows that the developed countries have made a much higher level of commitments than the developing countries and LDCs. 
In the Uruguay Round and the subsequent negotiations on financial services and telecommunications, the average number of sub-sectors in which developing countries made commitments was less than half of that for the developed countries, and the LDCs made only a quarter as many (Adlung and Roy, 2005). ${ }^{18}$

As shown in Table 2.2, all but one of the 24 developed countries made commitments in more than 80 sectors and sub-sectors, whereas the vast majority of the developing countries and transitional economies made commitments in 60 or fewer sectors and sub-sectors. Only 20 of the more than 100 developing countries and transitional economies made commitments in more than 80 sectors and sub-sectors, and 67 made commitments in 40 or less.

Table 2.2. Number of commitments made by developed countries and by developing countries and LDCs

\begin{tabular}{lcc}
\hline Sectors committed & Developed & Developing and LDCs \\
\hline$\leq 20$ & 0 & 44 \\
$21-40$ & 0 & 23 \\
$41-60$ & 0 & 10 \\
$61-80$ & 1 & 11 \\
$81-100$ & 1 & 11 \\
$101-120$ & 3 & 4 \\
$\geq 121$ & 19 & 5 \\
\hline
\end{tabular}

Source: 'Recent Developments in Services Trade - Overview and Assessment', S/C/W/94, 9 February 1999

Marchetti (2007) analysed the service commitments made in 14 sectors and sub-sectors by developed countries, countries in transition and developing countries, including LDCs, in the Uruguay Round, based on WTO data. His analysis showed that in eight of the sectors/sub-sectors, more than 90 per cent of the developed countries made commitments, compared with only one sector in the case of developing countries and LDCs. In only three sectors/sub-sectors did less than half of the developed countries make commitments, whereas in eight sectors/sub-sectors fewer than 30 per cent of the developing countries and LDCs made commitments.

\section{Commitments by mode of supply}

Not much work has been done analysing GATS commitments in terms of modes of supply. Mode 1, cross-border supply, is an area that is of particular interest to developing countries, but is often conditioned upon commercial presence (Mode 3). ${ }^{19}$ This generally puts it out of reach for the smaller developing countries, which often do not have service suppliers with the capacity to invest in other countries (Hoekman, 2009).

Marchetti (2007) has shown, based on an analysis of 37 sectors and sub-sectors, that the percentage of unrestricted commitments made by all groups of countries 
(developed, transitional, developing and LDCs) is considerably higher for Mode 2 than for the other modes, and that they are negligible in the case of Mode 4, which is of course of most interest to the developing countries. According to a recent WTO paper, 60 per cent of Mode 4 commitments are limited to highly skilled personnel, such as executives, managers and specialists, and two-thirds of these only permit such entry as intra-corporate transferees in conjunction with Mode 3 entry, ${ }^{20}$ which again generally puts it out of the reach of smaller countries. Twenty per cent cover business visitors negotiating the sale of services or setting up a commercial presence, making this again out of reach for most poor countries. Only 5 per cent cover other categories, none of them explicitly for lower skilled labour.

Interestingly, Marchetti also notes that a higher proportion of LDCs made unrestricted commitments in all four modes than the other groupings, perhaps because they did not understand the process.

\subsubsection{The Doha Development Round}

It is not possible within the scope of this study to compare the market-opening offers made by developed countries with respect to Mode 1 with those made by developing countries. ${ }^{21}$ However, some analysis has been done of the extent to which the developed countries have improved Mode 4 access in the DDA offers. ${ }^{22}$ The state of offers for Mode 4 in the Doha Round on the part of developed WTO members is mixed, with progress being shown by some countries and no progress at all by others.

Of the initial and revised services offers submitted by developed country WTO members in 2005, those for three countries - Australia, the USA, and Iceland - show no improvements in market access for Mode 4 over their Uruguay Round commitments. Japan's initial offer appears to be closely in line with existing conditions for admission of skilled professionals but these may be affected by economic needs tests which are retained in the offer. New Zealand's revised offer includes broad coverage of occupations of interest to developing countries but ties them to Mode 3, so that the categories only cover investment-related movement. Switzerland proposes to remove quotas on the overall number of work permits, but maintains its own interpretation of 'seeking employment', which excludes individual service providers.

Among the new and improved revised offers, that of Canada marks progress in Mode 4 in the area of transparency, proposing to indicate the exact conditions surrounding the entry and stay of the various categories of workers. The offers of the EC and Norway seem to go furthest in terms of market opening in Mode 4. The EC proposes to eliminate the economic needs test attached to most of the categories included in its schedule, and introduces a new category of graduate trainees, similar to what has been done in its EPA with CARIFORUM, which is of great interest to developing countries as a means of transfer of expertise (TN/S/O/EEC/Rev.1, June 2005). The EC entry for contractual service suppliers (CSS), which holds most potential for the export interests of developing countries, is improved in scope and duration in its 
offer, and a new category of independent professionals (IPs) is included. These marketexpanding proposals for Mode 4 in the offer for the 27 members of the EC represent very positive steps and should hopefully contribute toward creating momentum in Mode 4 liberalisation should the Doha Round be reinvigorated.

The revised offer of Norway (TN/S/O/NOR/Rev.1, June 2005) includes the additional category of specialists who would be authorised for temporary entry and work for up to two four-year periods, as well as a new category of 'natural persons providing services without being employed by a juridical person who has a commercial presence in Norway', which are effectively independent service suppliers. Economic needs tests are not required for these service suppliers, who can stay up to three months in any 12 month period, but must obtain a work permit and work within one of the scheduled sub-sectors.

\subsubsection{Regional trade agreements}

As discussed above, the modes of supply of most interest to developing countries, particularly the small and low-income ones, are Modes 1 and 4 . We therefore discuss each of these in turn.

\section{Mode 1 - Cross-border}

We have compared the number of Mode 1 commitments made by the developing and developing country parties in the positive list agreements we have reviewed. Despite the limitations of this approach, as discussed in the review of the Uruguay Round GATS commitments in Section 2.4.1, the results, shown in Table 2.3, are quite striking, showing that on average the developed countries made more than three times as many commitments as the developing countries.

In the case of negative list agreements, of course, the fewer the scheduled nonconforming measures, the more open is the trade in services. Our analysis of a number of negative list service agreements, summarised in Table 2.4, shows that, as expected, the developed countries have on average scheduled significantly fewer non-conforming cross-border measures than the developing countries -12 as opposed to $19 .{ }^{23}$ There are, however, some anomalies. In the North American Free Trade Agreement (NAFTA), Canada and the USA scheduled more non-conforming cross-border measures than Mexico. In its free trade agreement with Mexico, Japan scheduled 32 measures, compared with only 22 by Mexico. As in the case of the analysis of the negotiated outcomes of the GATS negotiations and the positive list RTAs, a simple comparison of the number of scheduled non-conforming measures fails to take account of the volume of trade affected by the measures, and is therefore a rather crude means of measuring asymmetries of outcome. ${ }^{24}$ 
Table 2.3. Number of Mode 1 commitments in GATS-type positive list service FTAs ${ }^{25}$

\begin{tabular}{|c|c|c|}
\hline Agreement & $\begin{array}{l}\text { Developed country } \\
\text { member(s) }\end{array}$ & $\begin{array}{c}\text { Developing country } \\
\text { member(s) }\end{array}$ \\
\hline Japan-Indonesia & 108 & 54 \\
\hline Japan-Brunei Darussalam & 93 & 20 \\
\hline Japan-Malaysia & 101 & 57 \\
\hline Japan-Philippines & 99 & 25 \\
\hline ASEAN-Australia-New Zealan & $\begin{array}{r}\text { Australia } 99 \\
\text { New Zealand } 93\end{array}$ & $\begin{array}{r}\text { Brunei Darussalam } 20 \\
\text { Cambodia } 67 \\
\text { Indonesia } 56 \\
\text { Laos } 22 \\
\text { Malaysia } 53 \\
\text { Myanmar } 18 \\
\text { Philippines } 19 \\
\text { Singapore } 49 \\
\text { Thailand } 27 \\
\text { Vietnam } 59\end{array}$ \\
\hline Australia-Thailand & 80 & 16 \\
\hline Average & 96 & 31 \\
\hline
\end{tabular}

Source: Author's analysis

Table 2.4. Number of non-conforming cross-border measures in services negative list FTAs

\begin{tabular}{lcc}
\hline Agreement & $\begin{array}{c}\text { Developed country } \\
\text { member(s) }\end{array}$ & $\begin{array}{c}\text { Developing country } \\
\text { members(s) }\end{array}$ \\
\hline $\begin{array}{l}\text { Strategic Economic } \\
\text { Partnership Agreement }\end{array}$ & $\begin{array}{c}\text { Chile 18 } \\
\text { Singapore 3326 }\end{array}$ \\
\hline NAFTA & $\begin{array}{c}\text { Canada 16 } \\
\text { United States } 9 \\
6\end{array}$ & Mexico 6 \\
US-Chile & 6 & 11 \\
\hline US-Peru & 6 & 10 \\
\hline US-Morocco & 5 & 34 \\
\hline US-Colombia & 15 & 33 \\
\hline Canada-Peru & 17 & 20 \\
\hline Canada-Chile & 16 & 13 \\
\hline Canada-Colombia & 32 & 8 \\
\hline Japan-Mexico & $\mathbf{1 2}$ & 22 \\
\hline Average & & $\mathbf{1 9}$ \\
\hline
\end{tabular}

Source: Author's analysis 


\section{Mode 4 - Temporary Movement}

In contrast to the lack of progress in the WTO, there has been an increasing amount of activity in trade negotiations at the regional level, with the completion of numerous RTAs, a large number of which incorporate Mode 4 as part of the package. Interesting initiatives have been taken by some developed countries in the regional context. Here we provide an overview of these developments. ${ }^{27} \mathrm{~A}$ more detailed discussion, on a country-by-country basis, is contained in Annex 5.

Many RTAs have gone much further than the GATS in the area of Mode 4 or temporary movement. Some developed countries have expanded the number of categories of skilled professionals covered, numbering more than 30 in agreements negotiated by the EU, Japan and Canada. Distinct progress has been made with respect to professional services. In addition, members of some RTAs have created innovative semi-skilled categories, such as technicians (Canada), nurses and care-workers (Japan), and installers (New Zealand). Moreover, in several agreements, the number of professionals (broadly defined) allowed to enter a country has been left uncapped, and these professionals have been guaranteed a longer length of stay and the possibility of long-term visa renewals.

The trading partners that have been the most willing to open their markets more widely for foreign workers from developing RTA partners have been countries that face labour shortages. Canada has shown itself the most generous in this respect, with Japan being selective and sector specific in responding to its labour market needs. The USA and the EU, who have both faced heavy inward migration flows from Latin America (in the case of the USA) and from North Africa and Eastern Europe (in the case of the EU), have been less willing to bind greater market openness for foreign workers. Nonetheless, the EU did expand its coverage of labour categories in its EPA with CARIFORUM members.

A final point is that the results are asymmetrical; developing countries have clearly not taken on as many commitments for labour categories or numbers from their partner countries. ${ }^{28}$ These precedents should provide encouragement to Commonwealth small and low-income countries that some of their priorities for forward movement in Mode 4 can eventually be addressed in RTAs with developed country partners when they are well-defined and well-negotiated, although the current world economic situation makes this a more challenging prospect for the time being.

\subsection{Technical assistance}

\subsubsection{The GATS}

Unlike many of the WTO Agreements, the GATS does not call for developed country members to provide technical assistance to developing country members. Instead, GATS Article XXV.2 states that technical assistance at the multilateral level is to be provided by the WTO itself, although it contains no commitment as to the amount of technical 
assistance to be provided or the time within which it is to be delivered. ${ }^{29}$ In practice, of course, many individual WTO members, as well as international organisations besides the WTO, have provided technical assistance in the area of services.

However, the amount of such technical assistance has been quite limited compared with that given with regard to other trade fields. This no doubt reflects the fact that the GATS imposes very few obligations on its members other than their negotiated commitments, and that technical assistance is not seen to be as necessary as in other areas, particularly with respect to agreements that impose significant obligations on all members, developed and developing, such as those on technical barriers to trade (TBT) and sanitary and phytosanitary (SPS) measures. An OECD report noted that 'the fact that the agreement does not require liberalisation or implementation of resource-intensive obligations is matched by its limited requirements on technical assistance and the absence of an obligation for Members to provide technical assistance to other Members' (OECD, 2006; emphasis in original).

The Doha Development Agenda Trade Capacity Building Database shows that even in 2002, when technical assistance with respect to services was far greater than in any other year between 2001 and 2007 (the last year reported), services represented only 0.03 per cent of all technical assistance activities, and only 6.5 per cent of all technical assistance dollars. The overall value of technical assistance dedicated to services between 2001 and 2007, US $\$ 42$ million, was dwarfed by the amounts provided in areas such as trade facilitation (US $\$ 1.51$ billion), regional trade agreements (US\$470 million), SPS (US\$405 million), and TBT (US\$250 million). ${ }^{30}$

\subsubsection{The Doha Development Round}

Article 14 of the Guidelines and Procedures for the Negotiations on Trade in Services (2001) (see Annex 4) calls for technical assistance to be provided on request in order to carry out national and regional assessments. In addition, the Modalities for the Special Treatment for Least-Developed Countries in the Negotiations on Trade in Services (2003), reproduced in Annex 4), specifically calls for technical assistance to continue to be provided to the LDCs in the following areas:

- Strengthening of domestic services capacity

- Building institutional and human capacity

- Undertaking appropriate regulatory reforms

- Carrying out national assessments of trade in services in overall and sectoral bases

Paragraph 10 of the Hong Kong Ministerial Declaration calls for targeted technical assistance to enable the developing countries and LDCs to participate effectively in the negotiations (WT/MIN(05)/DEC, 22 December 2005). This is reiterated in the 'July 2008 Package'. ${ }^{31}$ 


\subsubsection{Regional trade agreements}

Few of the RTAs reviewed in this paper contain provisions relating to technical assistance in the area of services. The EC-CARIFORUM FTA states that the parties agree to provide technical assistance designed to, inter alia, improve the export capacity of service suppliers and to develop and implement regulatory regimes in the sectors where CARIFORUM states have made commitments. In addition, the ASEAN-China and ASEAN-Korea agreements specify that assistance should be given to the newer ASEAN members in terms of strengthening their service capacity. Like the technical assistance provisions in the GATS, these provisions impose no commitments in terms of amount or timing.

Recent FTAs negotiated by the USA contain more substantive provisions on technical assistance. These are discussed in section 4.2 of this paper.

\subsection{Longer time periods for implementation}

\subsubsection{The GATS}

As noted in the introduction, developing countries were not given additional time to implement the general obligations of the GATS. Of course, the negotiating flexibility built into the agreement allowed countries, if they wished, to delay the implementation of market-opening commitments. Most of the pre-commitments, i.e. commitments to liberalise in the future, in the Uruguay Round, were in fact made by developing countries (OECD, 2006). Many of them were made with respect to basic telecommunications (Mattoo, 2002), to allow time for the industries to move from monopoly or duopoly positions to a more competitive system. ${ }^{32}$

\subsubsection{The Doha Development Round}

As also explained above, we have not been able to examine the DDA offers in detail other than for Mode 4, so cannot say to what extent offers by developing countries are for future rather than present market-opening. ${ }^{33}$

\subsubsection{Regional trade agreements}

Six of the examined North-South RTAs provide additional time for implementation of commitments, but in four cases this only applied to one or two sub-sectors and may have been of limited value. The ASEAN-Australia-New Zealand FTA gives some ASEAN members additional time to implement certain commitments with respect to telecommunications. ${ }^{34}$ The only one of the agreements examined here that provides additional implementation time for all sectors is the Trans-Pacific Strategic Economic Partnership Agreement (P4), which stipulates that the services chapter would not apply to Brunei Darussalam for two years.

Only two of the 12 South-South agreements reviewed here call for more time for 
implementation of obligations, though without laying out specific timeframes. The CARICOM agreement provides that disadvantaged countries ${ }^{35}$ are to be given more time to apply national treatment to services trade. And Decision 439 of the Andean Community, establishing a regime governing trade in services, provided that Bolivia and Peru were to be given preferential treatment with respect to deadlines and temporary exceptions from their obligations.

\section{7 'Best endeavour' provisions}

\subsubsection{The GATS}

The other SDT provisions in the GATS are mostly 'best endeavour' type clauses, which impose no binding obligations on the WTO members. These include the following:

- GATS Article IV calls for the facilitation of increased participation in world trade by developing country members through negotiated commitments relating to the strengthening of their domestic services capacity, the improvement of their access to distribution channels and information networks, and the liberalisation of market access in sectors and modes of supply of export interest to them. In addition, developed country members (and other members as far as possible), are to establish contact points to facilitate the access of service suppliers in developing country members to information concerning commercial and technical aspects of services supply, recognition of professional qualifications and the availability of services technology. ${ }^{36}$ Special priority is to be given to LDCs with respect to these requirements.

- GATS Article XV provides that negotiations with regard to subsidies are to recognise the role of subsidies in relation to the development programmes of developing countries and to take account of the needs of developing countries for flexibility in this area.

- GATS Article XIX.3 provides that the negotiating guidelines for each successive round of negotiations are to provide special treatment for LDCs. It also provides that negotiating guidelines for each round 'shall establish modalities for the treatment of liberalisation undertaken autonomously by members since previous negotiations. ${ }^{37}$

- Paragraph 5 (g) of the Annex on Telecommunications recognises the right of developing countries to place reasonable conditions on access to and use of public telecommunications networks and services necessary to strengthen telecommunications infrastructure and service capacity.

\subsubsection{Doha Development Round}

The Modalities for the Treatment of Autonomous Liberalisation (TN/S/6), adopted by the Council on Trade in Services in 2003, provides details as to how members are to 
claim credit for autonomous liberalisation in the course of the negotiations, including criteria for assessing the value of such liberalisation. They provide that the modalities are to be used, inter alia, 'as a means of promoting the economic growth and development of developing countries' (para. 13), and that in applying the modalities members are to take account of the flexibility given to developing country members as well as to their level of development (para. 14). We have classified this as a 'best endeavours' provision, since although it was considered a breakthrough in the services negotiations at the time, the Modalities create no obligation on members to grant credit for autonomous liberalisation.

The 'Elements Required to Complete the Services Negotiations', appended to the services group chairman's report of 28 July 2008 (T/N/S/34), part of the 'July 2008 Package', contains several hortatory statements concerning developing countries:

The negotiations shall aim at a progressively higher level of liberalisation of trade in services with a view to promoting the economic growth of all trading partners, and the development of developing and least-developed countries.... Responses [to requests] shall, where possible, substantially reflect current levels of market access and national treatment and provide new market access and national treatment in areas where significant impediments exist, in particular in sectors and modes of supply of export interest to developing countries, such as Modes 1 and 4, in accordance with Article IV of the GATS.

Members shall continue to give due consideration to proposals on trade-related concerns of small economies. In recognising their special situation, further liberalisation shall be in accordance with their development needs.

\subsubsection{Regional trade agreements}

Few of the agreements examined here contain 'best endeavour' provisions. The ASEAN-Australia-New Zealand FTA declares that the parties recognise the importance of facilitating the participation of newer ASEAN members (defined in the agreement as Cambodia, Laos, Myanmar and Vietnam) through specific commitments relating to, inter alia, strengthened service capacity, improved access to distribution channels and networks, and commitments in areas of export interest to the new ASEAN members. The ASEAN-China and ASEAN-Korea agreements call for assistance to the newer ASEAN members in terms of improved access to distribution channels and networks, and liberalisation of sectors and modes of interest to them. The Revised Treaty of Chaguaramas of 2001, setting out the CARICOM Single Market and Economy, states that the special needs of LDCs are to be taken into account with respect to the removal of restrictions on services.

\subsection{Pros and cons of special and differential treatment}

It is extremely difficult to assess the overall impact of SDT provisions. We are not aware of any studies that have been done to measure their overall value to developing 
countries, and it is therefore only possible to evaluate them qualitatively rather than quantitatively. In doing so it is important to distinguish between different types of SDT. Certain types of SDT are clearly beneficial to developing countries. Improved access to the markets of the developed countries obviously assists service suppliers in the smaller and poorer countries. Technical assistance and the ability to delay implementation assist the developing countries in carrying out their market-opening commitments, as well as the challenging task of setting up the sound regulatory structures that should accompany liberalisation of service sectors. 'Best endeavour' type provisions clearly have little or no value to developing countries other than their hortatory value and the moral pressure that they place on developed countries to act on their promises.

What is more difficult to assess is the impact of non-reciprocity - the explicit (in the case of the GATS) or implicit (in the case of most RTAs) recognition that developing countries are not expected to make as many market-opening commitments as the developed countries. ${ }^{38}$ As we have seen, this principle has been amply borne out in practice. The developed countries made more than twice as many commitments in the Uruguay Round as did the developing countries, and four times as many as the LDCs. The pattern for RTAs is similar. The key question is whether developing countries, particularly the poorer ones, benefit from providing a lower degree of market access in their commitments. ${ }^{39}$

As discussed in section 5 of this paper, assessing the cost of barriers to services trade and the impact of removing them is notoriously difficult. See, for example, Hoekman (2006) and Marchetti (2007). The basic data are poor, in part because, unlike in the case of goods, they are not collected at the border (with the exception of Mode 4). And each of the various ways in which experts have tried to measure the impact of liberalisation has serious conceptual problems. For example, determining the frequency of measures does not distinguish between those measures that actually have an impact on trade and those that are redundant, nor does it estimate the relative effect of different measures (Whalley, 2004). Differences in costs of services in different countries, also used in an attempt to measure the effect of liberalisation, can simply reflect differences in regulatory regimes or in the quality of services, rather than the impact of trade barriers (ibid.).

Nevertheless, there is a general consensus that protection against imports of trade in services can impose heavy costs on a country, since it imposes a tax not only on consumers, but also on producers in general. Marchetti (2004) has pointed out that:

Lack of storage capacity, poor stock management, unreliable transportation, expensive communications, poor product design, insufficient and costly financing, inadequate legal advice, or even outdated software products and processes are key determinants of firms' competitiveness and can even destroy otherwise favourable prospects for meeting domestic or export demand.

One study has concluded that Africa's poor trade performance is almost exclusively the result of poor infrastructure services (Hodge, 2002). 
It is generally accepted, based on many studies, that liberalisation of trade in services produces welfare benefits, not just for the global economy as a whole through the more productive use of resources, but also for individual liberalising countries. Competition in the domestic market is increased, reducing prices and offering more choice to consumers. Inflationary pressures are reduced, and foreign direct investment (FDI) is likely to increase, generating local employment and technology transfer. Intermediate costs for service providers, as well as for manufacturing and agricultural producers, will decrease as a result of competition, ${ }^{40}$ in turn making them more competitive. Thus, services liberalisation benefits all sectors of the economy, not just the services sector. Numerous studies have estimated that the gains from liberalisation of services trade would be far greater than liberalisation of trade in manufactured or agricultural goods. ${ }^{41}$ Some of these studies estimate the global benefits of services trade liberalisation, without focusing on the impact specifically on developing countries. However, others show that developing countries (and not just the larger ones) do indeed benefit from liberalised services trade. ${ }^{42}$ Konan and Maskus (2004) conclude that even using conservative assumptions, services liberalisation by one developing country, Tunisia, would increase welfare and GDP by more than 7 per cent, more than three times the benefit from liberalising trade in goods. Three-quarters of the gain would result from liberalisation of Mode 3 (FDI), which would increase real household income by 4 per cent. Liberalisation of Mode 1 (cross-border) would increase household income by 1 per cent.

If indeed developing countries benefit from liberalising trade in services under the right conditions and with appropriate regulatory structures in place, it could be argued that the principle of non-reciprocity actually harms developing countries by encouraging them to make fewer market-opening commitments and therefore obtaining fewer benefits from more open trade. The OECD has noted that 'given the economywide benefits of services liberalisation in general, including the importance of efficient infrastructure services in economic development, an important question to consider is whether a high degree of flexibility is in the best interests of development' (OECD, 2006). Of course, this principle may not be true, at least to the same extent, for the poorer countries. Countries such as India and Brazil, with their vast human and capital resources, are well equipped to deal with greater competition in the field of services. The poorer countries, however, feel that they will lose from services liberalisation because their industries are too small and inefficient to be able to compete with imported services. And they do not believe that they will gain from liberalisation of developed country service markets because their service suppliers are too small to compete there. The obvious mode of supply where they have a competitive advantage, Mode 4, is highly restricted by all countries. ${ }^{43}$

This is of course a large and complex subject, and it is beyond the scope of this paper to discuss it in detail. Most of the studies that demonstrate the benefits of opening services markets involve developed countries and more advanced developing countries, rather than LDCs. 
Because the benefits from market opening, as discussed above, can be so substantial, we believe that it is important to explore this subject further. Three countries, The Gambia, Lesotho and Sierra Leone, are often cited as examples of LDCs that made extremely broad GATS commitments in the Uruguay Round. Lesotho, for example, made commitments in 85 sub-sectors in all but two sectors (health and recreational, cultural and sporting services). ${ }^{44}$ As a result, there is substantial foreign investment, especially South African, in a number of key service sectors. For example, three of the four commercial banks are South African; one of the two mobile operators is South African and South African investors own part of the only fixed line operators; and the only passenger air service is South African. South African investors also hold significant stakes in the tourism and distribution industries. ${ }^{45}$ It would be useful, we believe, to commission a study of one or more of these three countries to determine the impact of the broad commitments. Has the presence of foreign investment in key sectors in fact resulted in greater efficiency and lower costs? Were adequate regulatory systems put in place to ensure competition? Have welfare gains outweighed any possible losses as a result of the crowding out of local service suppliers ${ }^{46}$

If studies show that even the poorer developing countries can benefit from opening their service sectors, they should be encouraged to do so, particularly in Mode 3. Care must be taken in deciding which sectors to liberalise. The greatest benefit is likely to come from opening network sectors, such as telecommunications and power transmission, as these are likely to produce benefits to all sectors of the economy more quickly, by improving infrastructure. ${ }^{47}$ It must be recognised that they will need ample time to carry out this opening in order to prepare for the adjustment and in particular to establish sound regulatory structures. Measures will need to be put in place to ensure that foreign affiliates of multinational corporations do not crowd out local competitors, and that their consumers are protected from monopolistic practices by creating and maintaining a competitive environment for network services. Regulations will also need to be drafted (or strengthened where they already exist) to ensure adequate prudential supervision of financial services. ${ }^{48}$ To achieve these necessary but complicated objectives, developing countries will need technical assistance, and this should be mandated. Indeed, as we suggest in Section 4.3.1 below, market opening might be made conditional on receipt of adequate technical assistance and the establishment of an appropriate regulatory system with adequately trained staff.

One way of protecting the poorer countries from excessive competition as a result of liberalising their service markets might be through a safeguard-type mechanism, although there are considerable difficulties with this. Article X of the GATS called for negotiations on emergency safeguard measures, the results of which were to go into effect within three years. In fact negotiations are still taking place, at least in theory, in the DDA, and reportedly have made little or no progress. The complexity of agreeing on a safeguard clause stems from the many difficult issues involved, which include the type of remedy to be applied (a freeze on existing commitments might not remedy the harm, but the mere possibility of a remedy that would require disinvestment would 
be a strong disincentive to FDI); the definition of the domestic industry (whether or not it should include foreign investors); whether the safeguard should be applied only to the mode in which the commitment had been made or to all modes; and whether or not compensation or retaliation should be mandated and if so, how to measure the amount. These issues would, of course, also be present in any effort to negotiate a safeguard measure in an RTA, which is no doubt to why so few RTAs contain effective safeguards. ${ }^{49}$ 